\title{
PENGARUH TUNJANGAN KINERJA TERHADAP KINERJA PEGAWAI PADA BAUK UNIVERSITAS NEGERI MAKASSAR
}

\author{
Sirajuddin Saleh, Muhammad Darwis \\ Dosen Prodi Pendidikan Administrasi Perkantoran \\ Fakultas Ilmu Sosial, Universitas Negeri Makassar
}

\begin{abstract}
ABSTRAK
Penelitian ini bertujuan untuk mengetahui: 1) Gambaran persepsi pengawai mengenai pemberian tunjangan kinerja pada BAUK Universitas Negeri Makassar; 2) Gambaran kinerja pegawai pada BAUK Universitas Negeri Makassar 3) Pengaruh tunjangan kinerja terhadap kinerja pegawai BAUK Universitas Negeri Makassar. Pendekatan yang digunakan adalah pendekatan kuantitatif dengan jenis penelitian korelasional. Variabel dalam penelitian ini yaitu pemberian tunjangan kinerja sebagai variabel bebas dan kinerja pegawai sebagai variabel terikat. Populasi dalam penelitian ini sebanyak 107 dengan sampel sebanyak 50\% (54 orang) yang diambil dengan menggunakan teknik proportinale random sampling. Teknik pengumpulan data yang dilakukan yaitu teknik angket observasi dan teknik dokumentasi. Data yang diperoleh melalui instrument angket, dianalisis dengan menggunakan statistik deskriptif dan inferensial setelah diuji persyaratan analisis.

Hasil penelitian menunjukkan bahwa: 1) Persepsi pegawai mengenai pemberian tunjangan kinerja termasuk sangat tinggi; 2) Kinerja pegawai termasuk kategori sangat tinggi; 3) Terdapat pengaruh positif dan signifikan antara pemberian tunjangan kinerja terhadap kinerja pegawai. Oleh karena itu disarankan kepada pimpinan pada BAUK Universitas Negeri Makassar, kiranya berupaya mempertahankan kinerjanya dan bahkan lebih ditingkatkan.
\end{abstract}

Kata kunci: Tunjangan Kinerja, Kinerja Pegawai.

\section{PENDAHULUAN}

Semakin kompleksnya tuntutan kinerja PNS semakin tinggi pula keluhan masyarakat akan buruknya kinerja pelayanan yang yang diberikan kepada masyarakat. Hal tersebut ditandai dengan beberapa indikator yang mencerminkan buruknya potret kinerja aparat pelayanan publik (yang sebagian besar dilayani oleh PNS) di Indonesia, antara lain pelayanan yang bertele-tele dan cenderung birokratis, biaya yang tinggi (high cost econom, pungutan-pungutan tambahan, perilaku aparat yang lebih bersikap sebagai pejabat ketimbang abdi masyarakat, pelayanan yang diskriminatif, mendahulukan kepentingan pribadi, golongan atau kelompok, termasuk kepentingan atasannya ketimbang kepentingan publik, adanya perilaku malas dalam mengambil inisiatif di luar peraturan, masih kuatnya kecenderungan untuk menunggu petunjuk atasan, sikap acuh terhadap keluhan masyarakat, lamban dalam memberikan pelayanan, kurang berminat dalam mensosialisasikan berbagai peraturan kepada masyarakat, dan sebagainya (Saleh, 2011).

Khusus kinerja PNS pada perguruan tinggi, hasil survei Direktorat Ketenagaan Direktorat Jenderal 
Pendidikan Tinggi Kementerian Pendidikan Nasional menunjukkan bahwa berbagai permasalahan yang terkait dengan rendahnya kinerja pelayanan tenaga kependidikan (tenaga administrasi) di perguruan tinggi khususnya dalam memberikan pelayanan administrasi umum, seperti personalia (kepegawaian), persuratan, pengelola arsip yang disebabkan oleh kompetensi pengetahuannya (Suharjono, 2010).

Oleh sebab itu optimalisasi kinerja pelayanan menjadi perhatian utama Kementerian Pendidikan dan Kebudayaan agar PNS dapat memberikan pelayanan yang prima yaitu kinerja pelayanan yang memenuhi Standar Pelayanan Minimal (SPM), memberikan pelayanan yang cepat, tepat dan akurat kepada masyarakat, dan sekaligus mendorong masyarakat untuk melakukan kontrol terhadap kinerja pelayanan yang diberikan.

Upaya memperbaiki kinerja pegawai di lingkungan Kementerian Pendidikan dan Kebudayaan termasuk di Universitas Negeri Makassar (UNM), maka pemerintah melalui Keputusan Presiden Nomor 88 Tahun 2013 yang pelaksanaannya diatur melalui Keputusan Menteri Pendidikan dan Kebudayaan Nomor 107 Tahun 2013 tentang Tunjangan Kinerja bagi Pegawai di Lingkungan Kementerian Pendidikan dan Kebudayaan, memberikan tunjangan kinerja kepada Pegawai Negeri Sipil di Lingkungan Kementerian Pendidikan dan Kebudayaan. Tunjangan kinerja diberikan kepada pegawai sesuai dengan target/sasaran kinerja yang ditetapkan setiap awal tahun yang dihitung berdasarkan kategori dan nilai capaian kinerja Pegawai yang dinilai pada setiap awal tahun. Tujuan pemberian tunjangan kinerja adalah untuk meningkatkan kinerja pegawai.

Beberapa hasil penelitian menunjukkan adanya pengaruh pemberian insentif/ tungangan kinerja/remunerasi terhadap kinerja pegawai. Hasil penelitian Budianto (2012:55) menyimpulkan bahwa "pemberian remunerasi di Lembaga Pemasyarakatan Klas II A Anak Blitar sangat berpengaruh dan sangat signifikan terhadap kinerja pegawainya". Hasil penelitian Gustika (2013:30) juga menyimpulkan bahwa "terdapat pengaruh positif dan signifikan pemberian remunerasi terhadap kinerja Polri di Polres Pasaman". Penelitian yang sama dilakukan Suncoko (2010:50) menyimpulkan bahwa "pemberlakuan remunerasi mempunyai pengaruh yang signifikan terhadap kualitas pelayanan pegawai KPPN Jakarta I yang dirasakan pelanggan".

Walaupun tunjangan kinerja pegawai telah diberikan sejak tahun 2013, akan tetapi kinerja yang ditampilkan oleh pegawai khususnya di Universitas Negeri Makassar belum menunjukkan perubahan yang signifikan dan bahkan cenderung tetap. Berdasarkan pengamatan penulis dan berbagai data awal yang ditemukan, menunjukkan bahwa kinerja pelayanan adminstrasi di UNM belum sesuai yang diharapkan. Hal ini dapat dilihat dengan masih banyaknya keluhan pegawai (dosen dan non dosen) serta mahasiswa terhadap kinerja pelayanan yang diterimanya.

\section{KAJIAN TEORI}

\section{Pengertian Tunjangan Kinerja}

Istilah tunjangan kinerja merupakan istilah yang masih baru dikalangan Pegawai Negeri Sipil. Istilah yang lazim dan sering digunakan oleh sebagian besar PNS adalah remunerasi. Remunerasi dikaitkan dengan peningkatan kinerja dan produktivitas sehingga bisa dijadikan unsur motivasi bagi pegawai untuk berprestasi. Dalam Kamus Besar Bahasa Indonesia (2000:946) kata remunerasi diartikan sebagai pemberian hadiah (penghargaan atas jasa dsb); imbalan. Remunerasi dapat diartikan sebagai sesuatu yang diterima pegawai sebagai imbalan dari kontribusi yang telah diberikannya kepada organisasi tempat bekerja. 
Imbalan yang diberikan kepada pegawai atas prestasi kerja atau kinerja yang ditampilkan disebut tunjangan kinerja. Pada pasal 1 ayat (3) Peraturan Menteri Pendidikan dan Kebudayaan Nomor 107 tahun 2013, disebutkan bahwa "Tunjangan Kinerja adalah penghasilan selain gaji yang diberikan kepada pegawai yang aktif berdasarkan kompetensi dan kinerja".

Tunjangan kinerja atau remunerasi dapat memberikan tambahan penghasilan kepada setiap pegawai, sehingga pegawai lebih konsentrasi dalam bekerja. Sistem remunerasi bagi setiap pegawai merupakan bagian dari reformasi birokrasi yang diterapkan oleh pemerintah. Pegawai negeri sipil yang selama ini hanya memperoleh remunerasi dalam bentuk pay for person dan pay for position, maka Kementerian Keuangan telah memulai reformasi birokrasi yang salah satunya merubah sistem remunerasi dari pertimbangan pribadi dan jabatan menjadi remunerasi berdasarkan grading (kelas jabatan), reformasi birokrasi perlu dan akan dilakukan secara bertahap untuk seluruh jajaran Pegawai Negeri, yang dimulai oleh Kementerian Keuangan, dengan merubah sistem remunerasi maka penghasilan pegawai selain gaji yang didasarkan pada golongan, juga diberikan penghasilan tambahan sebagai kontra prestasi dari kinerja saat ini. Adapun tambahan tersebut diperhitungkan dari pendidikan dan pengetahuan, pengalaman yang diperlukan, kompleksitas (kerumitan) pekerjaan, ruang lingkup pekerjaan, jenis dan sifat masalah yang harus dipecahkan, pengawasan yang diterima, tanggung jawab supervisi/pengawasan terhadap orang lain, dampak dari keputusan/akibat dari kesalahan, hubungan-hubungan kerja yang harus dilakukan dan kondisi lingkungan kerja. Hal ini menunjukkan bahwa remunerasi pegawai negeri sipil merupakan suatu hal yang dapat memberikan solusi bagi perbaikan kinerja pegawai.

\section{Dasar Pemberian Tunjangan Kinerja}

Pemberian tunjangan kinerja bagi Pegawai Negeri Sipil merupakan amanat pasal 2 Peraturan Presiden Nomor 88 tahun 2013 disebutkan bahwa "kepada pegawai yang mempunyai jabatan tertentu di lingkungan Kementerian Pendidikan dan Kebudayaan selain diberikan penghasilan sesuai ketentuan peraturan perundangundangan, diberikan tunjangan kinerja setiap bulan".

Untuk melaksanakan ketentuan pada Peraturan Presiden Nomor 88 tahun 2013 tersebut, Menteri Pendidikan dan Kebudayaan mengeluarkan Keputusan Nomor 107 tahun 2013 tentang Pemberian Tunjangan Kinerja bagi Pegawai di Lingkungan Kementerian Pendidikan dan Kebudayaan. Pada pasal 2 Permendikbud tersebut dijelaskan bahwa: "Pegawai berhak mendapatkan pembayaran Tunjangan Kinerja sesuai jabatannya berdasarkan Keputusan Pimpinan Unit Kerja Eselon I yang bersangkutan sesuai hasil evaluasi jabatan".

Ketentuan lebih lanjut mengenai PNS yang dapat diberikan tunjangan kinerja diatur pada Pasal 5 Permendikbud Nomor 107 tahun 2013. Kebijakan pemberian tunjangan kinerja dan kaitannya dengan peningkatan kinerja PNS merupakan bagian dari usaha reformasi birokrasi yang digagas pemerintah melalui Kementrian Pendayagunaan Aparatur Negara (Deputi MenPAN Bidang SDM Aparatur, 2009).

\section{Pengertian Kinerja}

Kata kinerja berasal dari bahasa Inggris yaitu performance yang berarti Kemampuan. Kinerja menurut Kamus Besar Bahasa Indonesia adalah sesuatu yang hendak dicapai, prestasi yang diperlihatkan dan kemampuan kerja. Kinerja dipergunakan oleh pimpinan untuk melakukan penilaian secara periodik mengenai efektivitas operasional organisasi dan pegawai berdasarkan 
sasaran, standar dan kriteria yang telah ditetapkan sebelumnya. Melalui penilaian kinerja, organisasi dan pimpinan dapat mengetahui sejauh mana keberhasilan dan kegagalan pegawai dalam menjalankan tugas yang diterima.

Rivai, (2004:309) mengemukakan beberapa pengertian kinerja yaitu: "Kinerja merupakan seperangkat hasil yang dicapai dan merujuk pada tindakan pencapaian serta pelaksanaan sesuatu pekerjaan yang diminta". Sedangkan menurut Simamora (2004:338), kinerja adalah "hasil kerja karyawan terhadap kontribusinya kepada organisasi selama periode waktu tertentu". Menurut Sutrisno (2010:151), kinerja adalah "hasil kerja yang telah dicapai seseorang dari tingkah laku kerjanya dalam melaksanakan aktivitas kerja. Sedangkan menurut Mangkunegara (2009:67), kinerja adalah "hasil kerja secara kualitas dan kuantitas yang dicapai oleh seseorang pegawai dalam melaksanakan tugasnya sesuai dengan tanggungjawab yang diberikan kepadanya".

$$
\text { Siagian }
$$

mengemukakan prestasi kerja yang disebut juga dengan kinerja "merupakan prestasi yang dicapai oleh seorang pegawai dalam melaksanakan tugas dan tanggung jawabnya”. Selanjutnya Mangkunegara (2005:9) mengemukakan pengertian prestasi kerja adalah "perbandingan hasil yang dicapai dengan peran serta tenaga kerja per satuan waktu, lazimnya per jam". Kemudian Simanjuntak (2005:1) mengemukakan pengertian prestasi kerja adalah "tingkat pencapaian hasil atas pelaksanaan tugas tertentu".

\section{Faktor-Faktor yang Mempengaruhi Kinerja Pegawai}

Sutrisno

(2010:151), mengemukakan bahwa umumnya orang percaya bahwa kinerja individu merupakan fungsi gabungan dari tiga faktor yaitu : 1) Kemampuan, perangai dan minat seorang pekerja. 2) Kejelasan dan penerimaan atas penjelasan peranan seorang pekerja. 3) Tingkat motivasi kerja.

Prestasi kerja merupakan hasil dari gabungan variabel individu dan variabel fisik dan pekerjaan serta variabel organisasi dan sosial. Dari uraian diatas, dapat dipahami bahwa kinerja seseorang dalam suatu organisasi merupakan hasil dari interaksi berbagai variabel yaitu individual dan lingkungan sosial. Di dalam penelitian ini pengukuran kinerja pegawai diarahkan pada enam aspek yang merupakan prestasi kunci pegawai adalah :

a. Hasil kerja. Tingkat kuantitas maupun kualitas yang telah dihasilkan dan sejauh mana pengawasan dilakukan.

b. Pengetahuan pekerjaan. Tingkat pengetahuan yang terkait dengan tugas pekerjaan yang akan berpengaruh langsung terhadap kuantitas dan kualitas dari hasil kerja.

c. Inisiatif. Tingkat inisiatif selama melaksanakan tugas pekerjaan khususnya dalam hal penanganan masalah-masalah yang timbul.

d. Kecekatan mental. Tingkat kemampuan dan kecepatan dalam menerima instruksi kerja dan menyesuaikan dengan cara kerja serta situasi kerja yang ada.

e. Sikap. Tingkat semangat kerja serta sikap yang positif dalam melaksanakan tugas pekerjaan.

f. Disiplin waktu dan absensi. Tingkat ketepatan waktu dan tingkat kehadiran.

\section{Penilaian Kinerja Pegawai}

Untuk mengetahui hasil kerja yang dicapai dan yang telah dikerjakan oleh setiap PNS dalam menjalankan tugas pokok dan fungsinya, diperlukan suatu pedoman sebagai alat ukur keberhasilan yang dilakukan oleh PNS tersebut. Untuk itu, Handoko (1987:135), menjelaskan bahwa "penilaian prestasi kerja (performance appraisal) adalah proses melalui mana organisasi-organisasi mengevaluasi atau menilai prestasi kerja 
karyawan". Sedangkan Siagian, (1989:114) mengemukakan bahwa yang dimaksud dengan penilaian kinerja adalah "proses pengukuran dan perbandingan dari hasil-hasil pekerjaan yang nyata dicapai dengan hasil-hasil yang seharusnya dicapai".

Soeprihanto (2009:24), mengemukakan beberapa aspek yang perlu dipertimbangkan dalam penilaian kinerja pegawai, yaitu: "prestasi kerja; tanggung jawab, ketaatan, prakarsa, kejujuran; dan kerjasama".

Selain itu dalam Peraturan Pemerintah Nomor 10 tahun 1979 menetapkan dasar penilaian kinerja Pegawai Negeri Sipil. Pada pasal 4 Peraturan Pemerintah Nomor 10 Tahun 1979 disebutkan unsur-unsur penilaian kinerja pegawai, sebagai berikut: "kesetiaan, prestasi kerja, tanggung jawab, ketaatan, kejujuran, kerjasama, prakarsa, dan kepemimpinan".

Penilaian kinerja Pegawai Negeri Sipil yang digunakan sejak berlakunya Peraturan Pemerintah Nomor 46 Tahun 2011 adalah penilaian prestasi kerja yang menggabungkan antara penilaian atas sasaran kerja pegawai dengan penilaian perilaku pegawai.

Sasaran Kerja Pegawai (SKP) merupakan rencana kerja tahunan pegawai yang disusun setiap awal tahun dan dievaluasi setiap akhir tahun. Penilaian SKP terdiri atas beberapa aspek, yaitu 1) Kualitas; 2) Kuantitas; 3) Mutu luaran; dan 4) Biaya. Sedangkan penilaian perilaku kerja pegawai sebagaimana disebutkan pada pasal 12 ayat (1) Peraturan Pemerintah Nomor 46 Tahun 2011, yaitu: "Orientasi pelayanan, integritas, komitmen, disiplin, kerjasama, dan kepemimpinan".

\section{METODE PENELITIAN}

Pendekatan yang digunakan pada penelitian ini adalah pendekatan kuantitatif menggunakan analisis deskriptif. Pendekatan ini digunakan untuk memperoleh gambaran tentang persepsi pegawai mengenai pemberian tunjangan kinerja kaitannya dengan kinerja pegawai. Adapun jenis penelitian ini adalah penelitian assosiatif.

Penelitian ini menggunakan dua variabel yaitu tunjangan kinerja sebagai variabel bebas $(\mathrm{X})$ dan kinerja pegawai sebagai variabel terikat (Y). Model hubungan antar variabel tersebut digambarkan sebagai berikut:

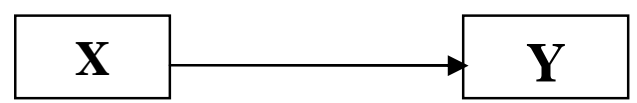

Gambar 2.

Hubungan Antar Variabel

Keterangan:

$\mathrm{X}=$ Tunjangan kinerja

$\mathrm{Y}=$ Kinerja pegawai

Variabel penelitian didefinisikan secara operasional, sebagai berikut: 1) Persepsi pegawai tentang pengaruh pemberian tunjangan kinerja terhadap kinerja pegawai adalah tanggapan pegawai mengenai penghasilan yang diberikan (selain gaji) berdasarkan kompetensi dan kinerja yang ditampilkan sesuai kelas jabatan masing-masing pegawai, dengan indikator: dasar penetapan kelas jabatan, besaran tunjangan, waktu pembayaran dan sanksi pengurangan; 2) Kinerja pegawai adalah hasil yang dicapai oleh pegawai dalam melaksanakan tugas-tugas yang diberikan, meliputi, SKP, orientasi pelayanan, integritas, komitmen, kerjasama.

Populasi dalam penelitian ini adalah semua pegawai pada BAUK Universitas Negeri Makassar sebanyak 107 orang. Sedangkan sampel diambil sebanyak 50\% atau sebanyak 54 orang. Sampel diambil dengan menggunakan teknik proporsional random sampling. Teknik pengumpulan data dalam penelitian ini yaitu angket, observasi dan dokumentasi.

Teknik analisis data yang digunakan untuk mengetahui gambaran 
persepsi pegawai mengenai pemberian tunjangan kinerja dan gambaran kinerja pegawai pada BAUK UNM, maka data yang terkumpul analisis dengan menggunakan teknik analisis deskriptif dalam bentuk persentase. Untuk mengambil kesimpulan, hasil analisis persentase dikonversi dengan pedoman sebagaimana dikemukakan oleh Riduwan (2004:67), sebagai berikut:

\section{Kurang dari 20\% Sangat Rendah (SR) \\ $21 \%-40 \% \quad$ Rendah (R) \\ $41 \%-60 \% \quad$ Sedang (S) \\ $61 \%-80 \% \quad$ Tinggi (T) \\ $81 \%-100 \% \quad$ Sangat Tinggi (ST)}

Untuk membuktikan hipotesis yang diajukan, maka data dianalisis dengan teknik statistik inferensial terlebih dahulu dilakukan uji normalitas dan uji linearitas sebagai persyaratan analisis.

Untuk mengetahui apakah data berdistribusi normal atau tidak dialkukan uji normalitas data. Uji normalitas data dilakukan dengan menggunakan program SPSS dengan uji One Sample Kolmogorov Smirnov. Sebuah hasil tes penelitian dinyatakan berdistribusi normal jika nilai probabilitas lebih besar dari 0,05 (nilai asym. Sig > 0,05). Dari hasil penelitian diperoleh bahwa pemberian tunjangan kinerja $(\mathrm{X})$ sebesar 0,153 dan kinerja pegawai (Y) sebesar 0,140. Dari hasil analisis tersebut diperoleh nilai probabilitas dari masing-masing variable penelitian lebih besar dari 0,05.

Sedangkan uji linearitas dengan menggunakan uji Anova (linear sig $<0.05)$ antara varaiabel kinerja pegawai $(\mathrm{X})$ dan tunjangan kinerja (Y) sig $0.000<0.005$ sehingga antara variabel kinerja pegawai dengan tunjangan kinerja terdapat hubungan linear.

\section{HASIL DAN PEMBAHASAN}

\section{Deskripsi Hasil Penelitian}

\section{1) Gambaran Persepsi Pegawai Terhadap Pemberian Tunjangan Kinerja}

Berdasarkan hasil penelitian melalui kuesioner menunjukkan bahwa persepsi pegawai mengenai pemberian tunjangan kinerja, tertera pada tabel berikut:

Tabel 1.

Gambaran persepsi pegawai terhadap pemberian tunjangan kinerja

\begin{tabular}{lcccc}
\hline \multicolumn{1}{c}{ Indikator } & $\mathrm{n}$ & $\mathrm{N}$ & Persentase & Kategori \\
\hline Sasaran kerja Pegawai (SKP) & 905 & 1080 & 83.80 & Sangat Tinggi \\
Orientasi Pelayanan & 710 & 810 & 87.65 & Sangat Tinggi \\
Integritas & 669 & 810 & 82.59 & Sangat Tinggi \\
Komitmen & 431 & 540 & 79.81 & Tinggi \\
Disiplin & 880 & 1080 & 81.48 & Sangat Tinggi \\
Kerjasama & 885 & 1080 & 81.94 & Sangat Tinggi \\
\hline Jumlah & 4480 & 5400 & 82.96 & Sangat Tinggi \\
\hline
\end{tabular}

Sumber: Diolah dari data hasil penelitian

Berdasarkan tabel 1 tersebut di atas, tampak bahwa persepsi pegawai mengenai pemberian tunjangan kinerja ditinjau dari dasar yang digunakan dalam penetapan tunjangan kinerja sebesar $90,56 \%$ atau tergolong sangat tinggi, besaran tunjangan kinerja yang diberikan sebesar $85,56 \%$ atau tergolong sangat tinggi, waktu pembayaran tunjangan sebesar $96,67 \%$ atau tergolong sangat tinggi dan sanksi pengurangan tunjangan sebesar $77,16 \%$.

Berdasarkan hasil analisis tersebut dapat dipahami bahwa persepsi pegawai mengenai pemberian tunjangan kinerja tergolong sangat tinggi atau sebesar $85,09 \%$. Ini menunjukkan bahwa pegawai pada Biro Administrasi Umum dan Keuangan Universitas Negeri Makassar memiliki berpersepsi yang positif dalam hal pemberian tunjangan kinerja.

Secara ringkas deskripsi tentang persepsi pegawai mengenai pemberian tunjangan kinerja dapat dilihat pada Gambar 3. 


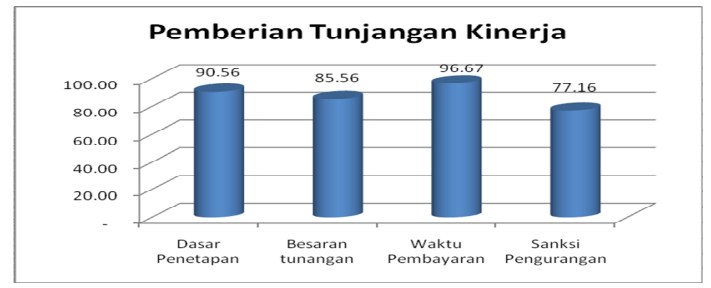

Gambar 3.

Gambaran Persepsi Pegawai Mengenai Tunjangan Kinerja

\section{Gambaran Kinerja Pegawai}

Berdasarkan hasil penelitian melalui kuesioner menunjukkan bahwa gambaran kinerja pegawai tertera pada Tabel 2.

Tabel 2

Gambaran Kinerja Pegawai

\begin{tabular}{lcccc}
\hline \multicolumn{1}{c}{ Indikator } & $\mathrm{n}$ & $\mathrm{N}$ & Persentase & Kategori \\
\hline Sasaran kerja Pegawai (SKP) & 905 & 1080 & 83.80 & Sangat Tinggi \\
Orientasi Pelayanan & 710 & 810 & 87.65 & Sangat Tinggi \\
Integritas & 669 & 810 & 82.59 & Sangat Tinggi \\
Komitmen & 431 & 540 & 79.81 & Tinggi \\
Disiplin & 880 & 1080 & 81.48 & Sangat Tinggi \\
Kerjasama & 885 & 1080 & 81.94 & Sangat Tinggi \\
\hline Jumlah & 4480 & 5400 & 82.96 & Sangat Tinggi \\
\hline
\end{tabular}

Sumber: Diolah dari data hasil penelitian

Berdasarkan hasil analisis persentase seperti pada tabel di atas maka dapat dideskripsikan bahwa kinerja pegawai ditinjau dari aspek pencapaian Sasaran Kerja Pegawai (SKP) sebesar $83,80 \%$ atau tergolong sangat tinggi, orientasi pelayanan sebesar $87,65 \%$ atau tergolong sangat tinggi, aspek integritas sebesar $82,59 \%$ atau tergolong sangat tinggi, aspek komitmen kerja sebesar $79,81 \%$ atau tergolong tinggi, aspek disiplin sebesar $81,48 \%$ atau tergolong sangat tinggi dan aspek kerja sama sebesar $82,96 \%$ atau tergolong sangat tinggi.

Berdasarkan uraian di atas, terlihat bahwa enam aspek kinerja pegawai hanya aspek komitmen kerja yang tergolong kategori tinggi. Sedangkan lima aspek lainnya termasuk kategori sangat tinggi. Dengan demikian dapat disimpulkan bahwa kinerja pegawai pada Biro Administrasi Umum dan Keuangan
Unoversitas Negeri Makassar sebesar $82,96 \%$ atau tergolong sangat tinggi.

Secara ringkas deskripsi tentang kinerja pegawai pada Biro Administrasi Umum dan Keuangan universitas Negeri Makassar dapat dilihat pada Gambar 4.

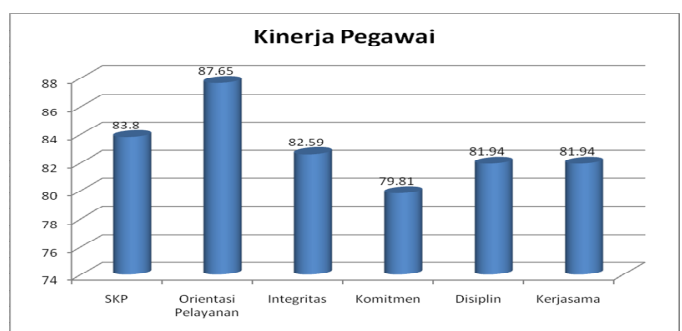

Gambar 4.

Gambaran Kinerja Pegawai

\section{Pengaruh Pemberian Tunjangan Kinerja terhadap Kinerja Pegawai pada BAUK Universitas Negeri Makassar}

\section{Hasil Analisis Korelasi Product Moment}

Untuk menjawab hipotesis yang diajukan serta untuk mengetahui seberapa kuat derajat keterkaitan antara variabel dependen dan independen maka data dianalisis dengan menggunakan analisis korelasi product moment. Kriteria pengujiannya adalah apabila $r$ hitung lebih besar dari $\mathrm{r}$ tabel pada taraf signifikansi $5 \%$ maka $\mathrm{H}_{0}$ yang menyatakan bahwa pemberian tunjangan kinerja tidak berpengaruh positif terhadap kinerja pegawai pada BAUK Universitas Negeri Makassar, ditolak dan $\mathrm{H}_{\mathrm{a}}$ yang menyatakan bahwa pemberian tunjangan kinerja berpengaruh positif terhadap kinerja pegawai pada BAUK Universitas Negeri Makassar, diterima. Hasil analisis dapat dilihat pada tabel berikut:

Tabel 5.

Hasil Analisis Korelasi Product Moment

Model Summary

\begin{tabular}{|l|l|r|r|r|}
\hline $\begin{array}{l}\text { Mode } \\
1\end{array}$ & $\mathrm{R}$ & R Square & $\begin{array}{c}\text { Adjusted R } \\
\text { Square }\end{array}$ & $\begin{array}{r}\text { Std. Error of } \\
\text { the Estimate }\end{array}$ \\
\hline 1 & $.561^{\mathrm{a}}$ & .314 & .301 & 2.43033 \\
\hline
\end{tabular}

a. Predictors: (Constant), Tuniangan Kinerja 
Berdasarkan hasil analisis korelasi product moment diperoleh gambaran bahwa nilai $\mathrm{r}$ hitung $(0,561)$ lebih besar dari $r$ tabel $(0,266)$ sehingga $H_{a}$ yang menyatakan bahwa pemberian tunjangan kinerja berpengaruh positif terhadap kinerja pegawai pada BAUK Universitas Negeri Makassar, diterima. Hasil tersebut menunjukkan pula bahwa koefisien korelasi antara variabel pemberian kinerja dengan kinerja pegawai sebesar 0,561 berada pada kategori sedang.

Dari tabel diatas menunjukkan pula bahwa koefisien determinasi yang melihat hubungan antar variabel yaitu $\mathrm{R}$ Square (0.314) yang berarti bahwa sumbangsih tunjangan kinerja terhadap kinerja pegawai 31,40\%. Sedangkan sisanya $68,60 \%$ dipengaruhi atau dijelaskan oleh variabel lain yang tidak dimasukkan dalam model penelitian ini.

\section{Hasil Analisis Regresi Linear Sederhana}

Analisis regresi linear sederhana digunakan untuk mengetahui apakah dalam model regresi variabel independen (pemberian tunjangan kinerja) berpengaruh signifikan terhadap variabel dependent (kinerja pegawai). Adapun hasil uji regresi sederhana dapat dilihat pada tabel 6 .

Tabel 6

Hasil Analisis Regresi Linear Sederhana

Coefficients

\begin{tabular}{|c|c|c|c|c|c|c|}
\hline \multirow[b]{2}{*}{ Madel } & & \multicolumn{2}{|c|}{ Unstandardized Coefficients } & \multirow{2}{*}{$\begin{array}{c}\text { Standardized } \\
\text { Coeficients } \\
\text { Beta }\end{array}$} & \multirow[b]{2}{*}{ \pm} & \multirow[b]{2}{*}{ Sig. } \\
\hline & & B & Std Error & & & \\
\hline \multirow[t]{2}{*}{1} & (Constant) & 36.017 & 9.621 & & 3.743 & .000 \\
\hline & Tuniangangan Kineria & .552 & .113 & .561 & 4.882 & .000 \\
\hline
\end{tabular}

Berdasarkan tabel di atas diperoleh $\mathrm{t}$ hitung sebesar 4.882. Tabel distribusi $\mathrm{t}$ dicari pada a $=5 \%: 22.5 \%$ (uji 2 sisi) dengan derajat kebebasan (df) n-k-1 atau $54-2-1=51$. Dengan pengujian 2 sisi ( signifikansi $=0.025)$ hasil diperoleh $\mathrm{t}$ tabel sebesar 2.00. oleh karena nilai $t$ hitung $4.882>\mathrm{t}$ tabel 2.00 , dan hasil ini terbukti signifikansinya yang lebih kecil dibanding 0,05. $(0,000<0.05)$. Dari hasil analisis tersebut maka dapat disimpulkan bahwa terdapat pengaruh yang signifikan antara tunjangan kinerja dengan kinerja pegawai.

Persamaan ini menunjukkan bahwa jika tidak ada tunjangan kinerja, maka kinerja pegawai pada BAUK Universitas Negeri Makassar sebesar 36,017. Koefisien regresi sebesar 0,552 menyatakan bahwa setiap penambahan (karena tanda +) satu unit pemberian tunjangan kinerja akan meningkatkan kinerja pegawai pada pada BAUK Universitas Negeri Makassar sebesar 0,552 .

\section{2) Pembahasan Hasil Penelitian}

Hasil penelitian dengan analisis deskriptif menunjukkan bahwa persepsi pegawai terhadap pemberian tunjangan kinerja sangat tinggi $(85,09 \%)$ Data ini menunjukkan bahwa pemberian tunjangan kinerja sudah memenuhi harapan pegawai. Tunjangan kinerja yang diterima pegawai terbukti dapat meningkatkan kinerjanya. Hal ini menunjukkan hasil bahwa program perbaikan penghasilan dalam bentuk tunjangan kinerja dapat menciptakan kesiapan organisasi dan sumber daya manusianya untuk meningkatkan kinerjanya.

Terdapat beberapa unsur yang dijadikan sebagai indikator pemberian tunjangan kinerja yaitu faktor dasar penetapan, besaran tunjangan, waktu pembayaran dan sanksi pengurangan tunjangan. Dari keempat unsur tersebut kesemuanya dipersepsikan oleh pegawai dengan kategori sangat tinggi kecuali unsur sanksi pengurangan tunjangan apabila tidak mencapai sasaran kinerja. Hal ini menunjukkan bahwa pegawai belum sepenuhnya bersedia menerima sanksi pengurangan tunjangan apabila tidak memenuhi target kinerja yang ditetapkan 
atau melanggar ketentuan yang telah ditetapkan.

Beberapa sanksi pengurangan tunjangan kinerja sebagaimana dijelaskan pada pasal 11 Peraturan Mendikbud Nomor 107 Tahun 2013, yang menyaatakan bahwa pegawai dijatuhi sanksi pengurangan tunjangan kinerja apabila pegawai yang tidak masuk kerja atau tidak berada di tempat tugas selama 7,5 (tujuh koma lima) jam atau lebih dalam sehari, terlambat masuk kerja, pulang sebelum waktunya, tidak mengisi daftar hadir; dan pegawai yang dijatuhi hukuman disiplin.

Hasil penelitian ini pula memberikan gambaran bahwa kinerja pegawai pada BAUK Universitas Negeri Makassar termasuk kategori sangat tinggi ditinjau dari aspek orientasi pelayanan, integritas, komitmen, disiplin kerja dan kerja sama.

Tingginya kinerja pegawai berdasarkan hasil analisis data salah satunya disebabkan oleh pemberian tunjangan kinerja. Oleh karena itu maka sangatlah tepat apabila pemerintah melakukan reformasi birokrasi secara bertahap untuk seluruh jajaran Pegawai Negeri dengan merubah sistem remunerasi dimana penerimaan pegawai selain gaji yang didasarkan pada golongan, juga diberikan penghasilan tambahan sebagai kontra prestasi dari kinerja saat ini. Adapun tambahan tersebut diperhitungkan dari pendidikan dan pengetahuan, pengalaman yang diperlukan, kompleksitas (kerumitan) pekerjaan, ruang lingkup pekerjaan, jenis dan sifat masalah yang harus dipecahkan, pengawasan yang diterima, tanggung jawab supervisi/pengawasan terhadap orang lain, dampak dari keputusan/akibat dari kesalahan.

Hasil penelitian ini pula menggambarkan bahwa tunjangan kinerja merupakan suatu hal yang dapat memberikan solusi bagi perbaikan kinerja pegawai. Kinerja pegawai merupakan hasil sinergi dari sejumlah faktor. Faktor-faktor tersebut adalah faktor lingkungan internal organisasi, faktor lingkungan eksternal, dan faktor internal pegawai.

Dari beberapa faktor yang disebutkan di atas, maka lingkungan internal organisasi sangat menentukan. Dalam melaksanakan tugasnya, pegawai memerlukan dukungan organisasi tempat ia bekerja. Dukungan tersebut sangat memengaruhi tinggi rendahnya kinerja pegawai. Oleh karena itu, manajemen organisasi harus menciptakan lingkungan internal organisasi yang kondusif sehingga dapat mendukung dan meningkatkan kinerja pegawai.

\section{SIMPULAN}

Berdasarkan hasil analisis data sebagaimana diuraikan pada bab sebelumnya maka dapat disimpulkan bahwa:

1. Persepsi pegawai pada BAUK Universitas Negeri Makassar mengenai pemberian tunjangan kinerja ditinjau dari aspek dasar penetapan kelas jabatan, besaran tunjangan, waktu pembayaran dan sanksi pengurangan termasuk kategori sangat tinggi.

2. Kinerja pegawai BAUK Universitas Negeri Makassar ditinjau dari aspek ketercapaian sasaran kerja, orientasi pelayanan, integritas, komitmen, disiplin, dan kerjasama termasuk kategori sangat tinggi.

3. Pemberian tunjangan kinerja berpengaruh positif dan signifikan terhadap kinerja pegawai pada BAUK Universitas Negeri Makassar.

\section{DAFTAR PUSTAKA}

Boedianto. S. 2012. Pengaruh Pemberian Remunerasi Terhadap Kinerja Pegawai pada lembaga Pemasyarakatan Kelas II A Blitar. Jurnal Ilmu Manajemen 
Revitalisasi. Volume 1 Nomor 3 Desember 2012. 1-10.

Gustika. 2013. Pengaruh Pemberian Remunerasi terhadap Kinerja Anggota Polri Polres Pasaman. EJurnal Apresiasi Ekonomi Vol. 1 Nomor 1 januari 2013.31-40.

Handoko. T. Hani. 1987. Manajemen. Yogyakarta. BPFE

Mangkunegara, Anwar, P 2005. Pengembangan Sumber Daya Manusia Pegawai Negeri Sipil. Jakarta: LAN RI

2009.

Manajemen Sumber Daya Manusia Perusahaan.

Bandung. PT. remaja Rosdakarya.

Peraturan Pemerintah Nomor 46 tahun 2011. Penilaian Prestasi Kerja Pegawai Negeri Sipil. Jakarta.

Peraturan Presiden Nomor 88 Tahun 2013. Tunjangan Kinerja Pegawai di Lingkungan Kementerian Pendidikan dan Kebudayaan. Jakarta.

Permendikbud Nomor 107 tahun 2013. Tunjangan Kinerja bagi Pegawai di Lingkungan Kementerian Pendidikan dan Kebudayaan. Jakarta: Kemdikbud

Poerwadarminta, W.J.S. 2000. Kamus Besar Bahasa Indonesia. Jakarta: Balai Pustaka.

Riduwan. 2004. Rumus dan data dalam Analisis Statistika. Bandung. Alfabeta.

Rivai, Veithzal, 2004. Manajemen Sumber daya Manusia. Jakarta: Rajawali Pers
2007. Kepemimpinan dan Perilaku Organisasi. Jakarta: PT Raja Grafindo Persada.

Saleh, S. 20011. Pelayanan Administrasi Kepegawaian pada FIP Universitas Negeri Makassar. Makassar: Tesis. PPs Universitas Negeri Makassar. Makassar.

Sancoko. B. 2010. Pengaruh remunerasi terhadap Pelayanan Publik di KPPN I Jakarta. Jurnal Ilmu Administrasi dan Organisasi, Jan-Apr 2010, ISSN 0854-3844 Volume 17, Nomor 1: $1-10$.

Siagian. Sondang. P. 1997. Manajemen Sumber Daya Manusia. Jakarta: Bumi Aksara.

Simamora, H. 2004. Manajemen Sumber Daya Manusia. Yogyakarta: STIE YPKN.

Soeprihanto. John. 2009. Penilaian Kinerja dan Pengembangan Karyawan. Yogyakarta: BPFE.

Suharjono. 2010. Pengantar Pelayanan Prima bagi Tenaga Kependidikan di Perguruan Tinggi Negeri. Bahan Ajar. Disajikan dalam Penataran Pelayanan Prima. Manado, 5-8 Desember 2010.

Supriyanto. 2001. Pengukuran Tingkat Kepuasan Pelanggan untuk Menaikkan Pangsa Pasar. Jakarta: Rineka Cipta.

Sutrisno. H. Edi. 2010. Manajemen Sumber Daya Manusia. Jakarta. Prenada Media Group. 